Удк 630.181:581.132:58.087

DOI https://doi.org/10.32848/0135-2369.2020.73.13

\title{
ВУГЛЕЦЕПОГЛИНАЛЬНА ЗДАТНІСТЬ СОСНОВИХ ЛІСОВИХ НАСАДЖЕНЬ ЖИТОМИРСЬКОГО ПОЛІССЯ
}

\author{
Мороз В.В. - кандидат сільськогосподарських наук \\ https://orcid.org/0000-0002-1457-4641 \\ НИкИтюк Ю.А. - кандидат сільськогосподарських наук \\ https://orcid.org/0000-0002-1274-7668 \\ Житомирський національний агроекологічний університет
}

Постановка проблеми. За останні десятиріччя кліматичні зміни в призвели до низки негативних чинників, серед яких зникнення окремих видів рослин і тварин, посухи, ускладнення вирощування сільськогосподарських культур, всихання і захворювання деревних порід та ін. [1; 4].

3 огляду на зазначені фактори на Міжнародних кліматичних переговорах $\mathrm{OOH}$ (COP21) у 2015 p. була підписана Паризька угода. Із 197 країн світу, які узяли участь у підписанні угоди, 176 її ратифікували. Україна була однією з перших країн світу, яка на державному рівні затвердила угоду $[11 ; 12]$.

Головна мета Паризької кліматичної угоди - не допустити зростання глобальної середньої температури повітря більше ніж $2{ }^{\circ} \mathrm{C}$ (за можливості - не більше $1,5^{\circ} \mathrm{C}$ ) щодо показників до початку промислової революції, коли людство почало спалювати величезну кількість викопного палива, йдеться про історичний період до $1750-x$ рp. - до того як в Англії розпочалась промислова революція, що пізніше поширилася країнами Європи [11; 12].

Утримання глобального потепління на рівні 1,5$2{ }^{\circ} \mathrm{C}$ потребує швидкого зменшення антропогенних викидів парникових газів в оточення та повного їх усунення до другої половини XXI ст. [4; 11].

Для вирішення локальних і глобальних екологічних проблем Паризька угода передбачає активне використання торгівлі квотами на викиди забруднюючих речовин. "Квота» - це дозвіл, сертифрікат на викиди, однієї тони еквівалента $\mathrm{CO}_{2}$ за певний період часу, який може бути передано відповідно до правил схеми. Торгівля квотами емісії парникових газів (ПГ) (англ. Emissions trading) - ринковий інструмент зниження викидів парникових газів в атмосфреру $[1 ; 8 ; 14]$. Середня вартість однієї квоти на викиди парникових газів становить 18 доларів США [12], якщо припустити можливість продажу різниці між викидами і депонуванням вуглецю, то Україна мала б значний прибуток від реалізації квот. Враховуючи вищезазначене, Міністерство енергетики та захисту довкілля України розглядає шляхи впровадження системи торгівлі квотами на викиди парникових газів [1].

На конференції ООН зі зміни клімату в Парижі (2015) розглядалася роль лісів у боротьбі зі зміною клімату. Важливість лісів ґрунтується на рамковій програмі ООН, схваленій у 2013 р., - REDD + (скорочення викидів у результаті знеліснення і деградації лісів) [16].

Отже, збереженню наявних та збільшенню кількості природних поглиначів вуглецю за допомогою покращеного управління лісами та іншими рослинними насадженнями і ґрунтами науковці надають особливу увагу.
Аналіз останніх досліджень і публікацій. Через моделювання продуктивності лісових насаджень і оцінки їх вуглецепоглинальної здатності визначають хід процесів у лісових екосистемах із метою екологічного моніторингу сталого ведення лісового господарства.

У науці низкою вітчизняних вчених, зокрема П.І. Лакидою (2006, 2009, 2011), С.І. Миклушем (2011), М.А. Голубом (2003), В.І. Білоусом (2009), В.П. Пастернаком (2011), Р.Д. Василишиним (2014) та ін., розроблено шляхи та методи оцінки біологічної продуктивності лісових насаджень.

Наші наукові дослідження доповнено розробками іноземних науковців у галузі оцінки біопродуктивності лісових насаджень: Д.Г. Щепащенко, А.З. Швиденко, В.С. Шалаев, Ю.П. Демаков, А.С. Пуряев, І.А. Алексеев, І.П. Курненкова, А.С. Аткин та ін. [2; 6; 17; 20], та удосконалено методами математичного моделювання 3 використанням методик А.І. Герасимович, Я.І. Матвєєва, А.І. Кобзаря [5; 9].

Мета статті. Метою наших досліджень було розробити математичні залежності конверсійних коефіцієнтів для встановлення накопичення фітомаси та обсягів поглинутого вуглецю сосновими лісовими насадженнями Житомирського Полісся за їх віком, застосовуючи методичні підходи вітчизняних та іноземних науковців.

Матеріали та методика досліджень. Збір дослідного матеріалу проводився в державних підприємствах 2016-2019 рр.: Баранівське ЛМГ (у лісництвах Баранівське, Зеремлянське, Явненське, Адамівське, Биківське, Довбинське, Кам'янобрідське, Довишське), Білокоровицьке ЛГ (у лісництвах - Білокоровицьке, Жубровицьке, Замисловицьке, Озорянське, Радовельське, Поясківське, Зубковицьке, Тепеницьке, Броницьке, Замисловицьке), Городницьке ЛГ (у лісництвах - Городницьке, Липинське, Броницьке, Надслучанське, Кленівське, Липинське, Червоновольське), Ємільчинське ЛГ (у лісництвах - Барашівське, Гартівське, Глумчанське, Ємільчинське, Жужельське, Королівське, Кочичинське), Житомирське ЛГ (у лісництвах - Новозаводське, Тригірське, Богунське, Березівське, Корабельне, Левківське, Пилипівське, Станишівське), Коростенське ЛМГ (у лісництвах - Бехівське, Омелянівське, Турчинецьке, Ушомирське, Шершнівське, Дубовецьке, Коростишівське, Кропивнянське, Смолівське, Івницьке), Малинське ЛГ (у лісництвах - Чоповицьке, Малинське, Любовицьке, Іршанське, Слобідське, Чоповицьке, Українківське), Народицьке СЛГ (у лісництвах - Кліщівське, Народицьке (ландшафтний заказник місцевого значення «Древлянський»), Базарське, Заліське, Закусилівське, Давидківське, Радчанське), НовоградВолинський ДЛМГ (у лісництвах - Малоцвілянське, 
Нов-Волинське, Курчицьке, Пилиповецьке, Пищівське (ландшафтний заказник місцевого значення «Пікельський»), Ярунське), Овруцький СЛГ (у лісництвах - Борутинське, Журбенське, Виступовицьке, Ситовецьке, Коптівщинське, Овруцьке, Прилуцьке, Ігнатпільське, Піщаницьке, Гладковицьке, Бережестське), Олевське ЛГ (у лісництвах - Руднянське, Покровське, Камянське, Олевське, Юрівське, Журжевицьке, Сновидовицьке, Хочинське, Комсомольське), Словечанський лісгосп АПК (у лісництвах Бігунське, Словечанське, Слобідське, Перебродське, Овруцьке, Рокитнянське, Гладковицьке).

Наші дослідження були зосереджені на відборі дослідного матеріалу в різновікових соснових насадженнях I-IV категорій лісів Житомирського Полісся.

Тимчасові пробні площі закладали в соснових насадженнях згідно із СОУ 02.02-37-476:2006 «Пробні площі лісовпорядні. Метод закладання». Загальна кількість пробних площ - 104.

Фітомасу деревини та кори в абсолютно сухому стані визначали через їх об'єм за довідковими таблицями $[7 ; 19]$ та множили на середню базисну щільність [3; 10;13]:

$$
m=V \times \rho_{\text {баз }},
$$

де $m$ - фітомаса компонента, кг; $V$ - об'єм ком-

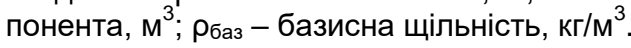

Для встановлення фітомаси крони сосни звичайної використано рівняння, яке запропонували А.С. Аткин та Л.І. Аткина [2; 17]:

$$
m_{\text {крони }}=8,379+0,087 \times m_{\text {стовбура, }}
$$

де $m_{\text {крони }}$ - фрітомаса крони, кг; $m_{\text {стовбура }}-$ фрітомаса стовбура, кг.

Загальну фітомасу дерева визначали суму окремих фітофрракцій дерева (кора, деревина, крона).

Запаси вуглецю в деревостанах встановлювали на підставі даних запасу стовбурів сосни звичайної за допомогою конверсійно-об'ємних коефіцієнтів, що представляють собою відношення фітомаси окремих фракцій до запасу деревини і залежних від віку деревостану [2; 6; 17].

Математичне моделювання здійснювали за методикою A.І. Кобзаря, A.І. Герасимович, Я.І. Матвєєва [5; 9] за допомогою Microsoft Excel.

Результати досліджень. Проблема вивчення пулів вуглецю в лісових екосистемах тісно пов'язана з тенденціями в зміні клімату. Встановлення різниці між викидами вуглецю та його акумулюванням у фотомасі дерев дасть змогу достовірно прогнозувати стан навколишнього середовища та виконувати вимоги Паризької угоди.

Аналізуючи кліматичні зміни Житомирського Полісся за період 1968-2018рр., ми визначили тенденцію зростання середньорічної температури повітря на $2,5^{\circ} \mathrm{C}$ (рис. 1 ).

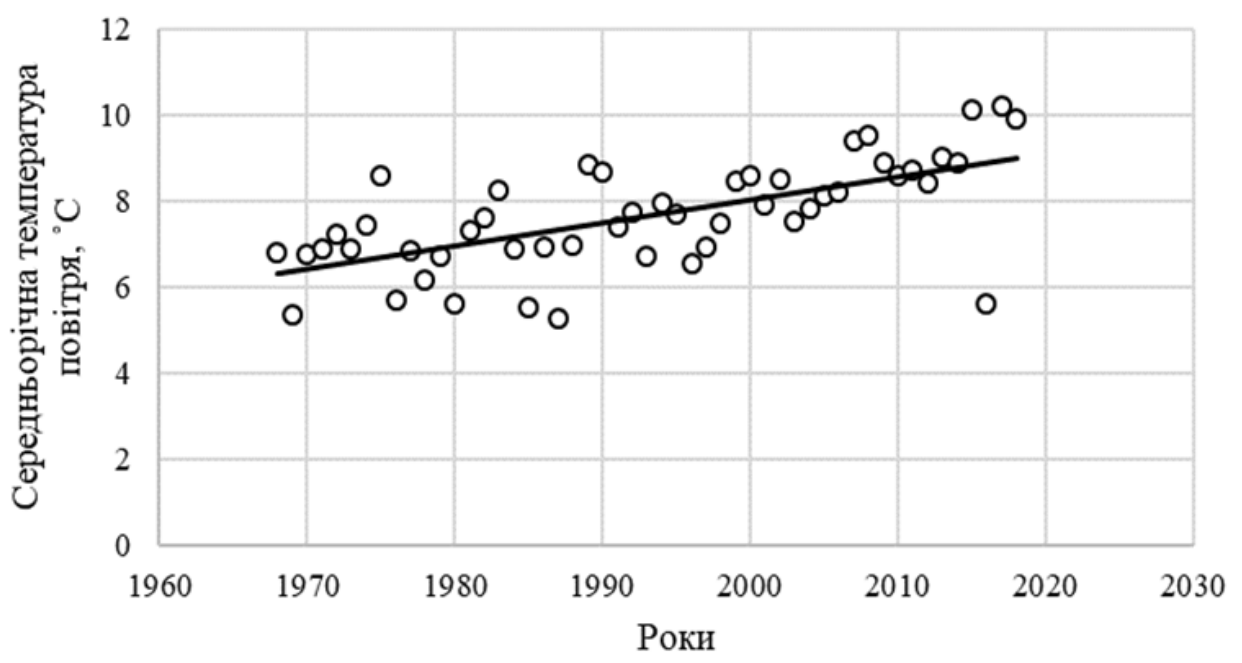

Puс. 1. Середньорічна температура повітря за період 1968-2018 рр.

Такі зміни мають негативний вплив на насадження, останні роки спостерігається всихання соснових насаджень. Згідно з останнім публічним звітом Державного агентства лісових ресурсів України станом на 1 січня 2019 р. загальна площа всихання лісів становить 440000 га, 3 них сосни звичайної - 243000 га.

За даними державного агентства лісових ресурсів в Україні серед 30 головних лісотвірних порід сосна звичайна (Pinus silvestris L.) займає $35 \%$ і є одним із перспективних вуглецепоглиначів держави (рис. 2).

Згідно з Державним лісовим кадастром станом на 1 січня 2011 р. у Житомирському Поліссі площа вкритих лісовою рослинністю соснових лісових ділянок становить 776,7 тис. га, що становить 59\% від решти насаджень (рис. 3).

Розподіл площ лісових ділянок під насадженнями за категоріями лісів у Житомирському Поліссі вказав, що більшість займають соснові ліси IV категорії (експлуатаційні), їх частка становить $68 \%$, а найменшу площу займають ліси III категорії (захисні) - 6\% (рис. 4).

За фрормулами 1 і 2 встановлено фрітомасу деревини, кори та крони сосни звичайної та побудовано кореляційну матрицю між показниками надземної фрітомаси в абсолютно сухому стані та таксаційними показниками дерева (діаметр і висота). Результати аналізу представлено у таблиці 1. 


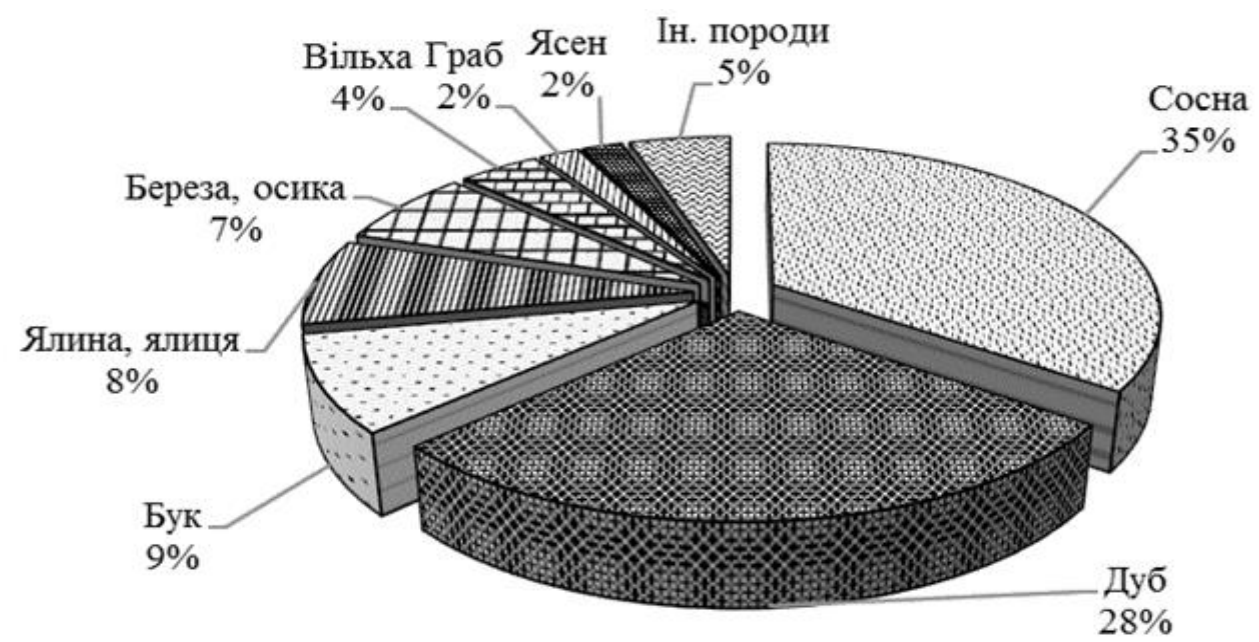

Puс. 2. Розподіл площі лісів України за переважаючими деревними породами (заідно з даними Державного агентства лісових ресурсів України) [15]

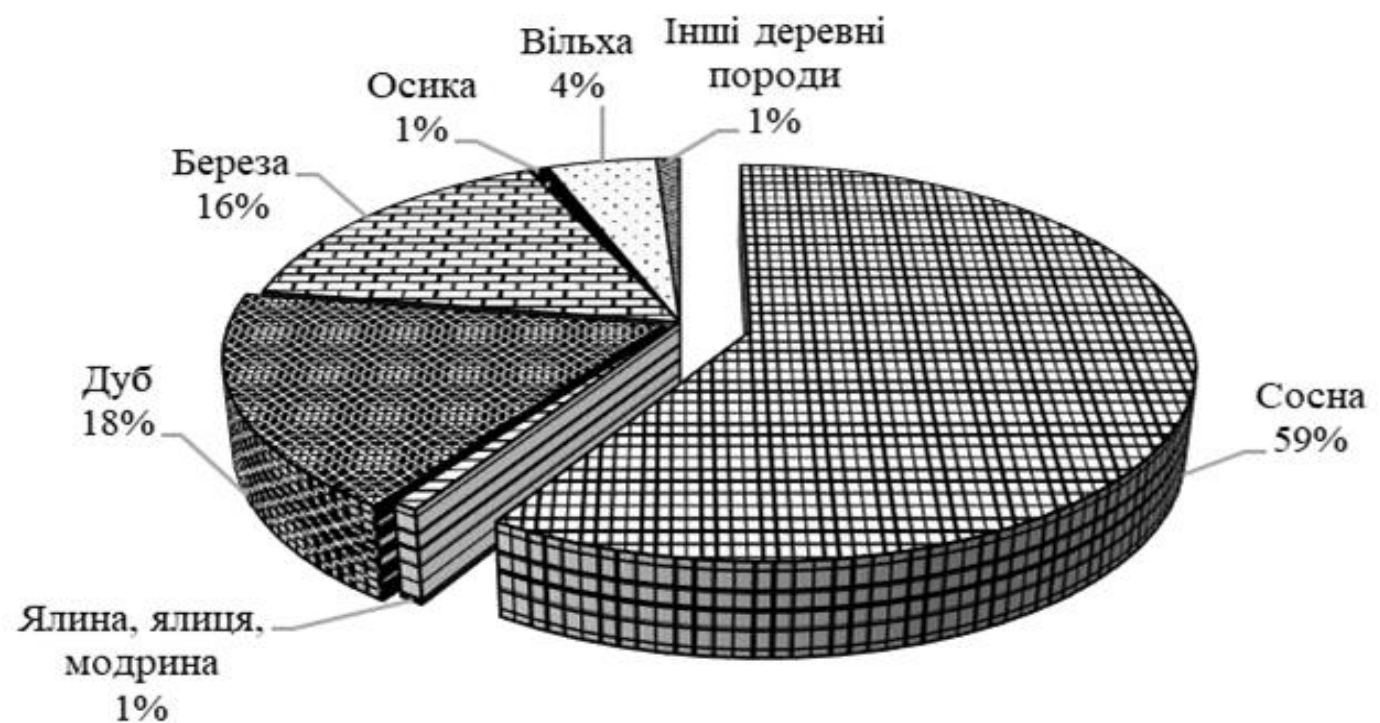

Рис. 3. Розподіл площі вкритих лісовою рослинністю соснових лісових ділянок

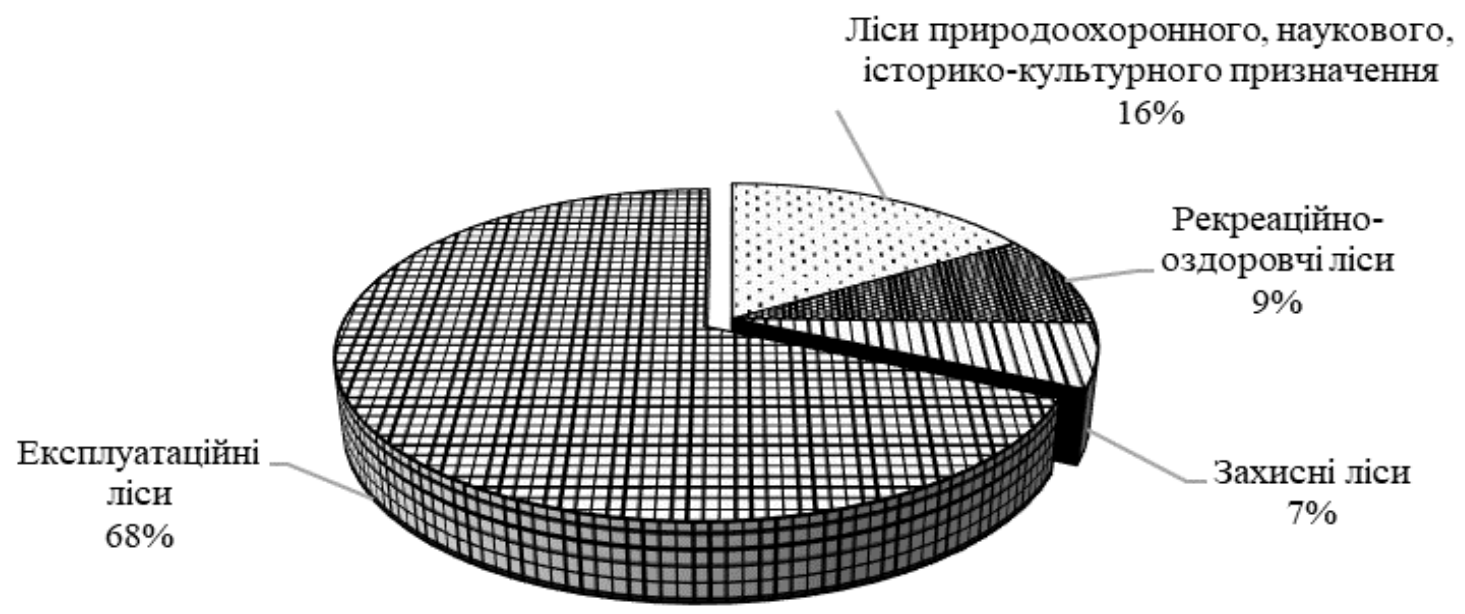

Рис. 4. Розподіл за категоріями соснових лісових ділянок у Житомирському Поліссі 
ЗРОШУВАНЕ ЗЕМЛЕРОБСТВО. Збірник наукових праць. Випуск 73

Таблиця 1 - Кореляційна матриця основних біометричних показників соснових деревостанів та надземної фітомаси в абсолютно сухому стані

\begin{tabular}{|c|c|c|c|c|c|c|c|c|c|}
\hline Показники & 站 $\frac{m}{\frac{m}{2}}$ & $\begin{array}{l}\text { 움 } \\
\text { 욤 } \\
\text { 은 }\end{array}$ & $\begin{array}{l}\stackrel{\vdash}{ \pm} \\
\stackrel{.}{\bar{T}} \\
\text { ம }\end{array}$ & 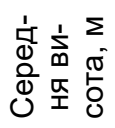 & 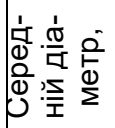 & 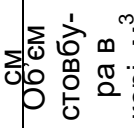 & 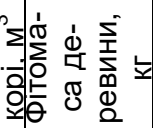 & 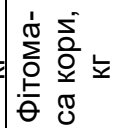 & 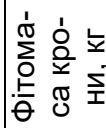 \\
\hline Вік, років & 1,00 & - & - & - & - & - & - & - & - \\
\hline Повнота & $-0,007$ & 1,00 & - & - & - & - & - & - & - \\
\hline Бонітет & 0,076 & $-0,071$ & 1,00 & - & - & - & - & - & - \\
\hline Середня висота, м & 0,776 & 0,033 & $-0,361$ & 1,00 & - & - & - & - & - \\
\hline Середній діаметр, см & 0,863 & $-0,011$ & $-0,133$ & 0,894 & 1,00 & - & - & - & - \\
\hline Об'єм стовбура в корі, м & 0,850 & 0,010 & $-0,061$ & 0,815 & 0,955 & 1,00 & - & - & - \\
\hline Фітомаса деревини, кг & 0,850 & 0,010 & $-0,060$ & 0,814 & 0,955 & 1,00 & 1,00 & - & - \\
\hline Фітомаса кори, кг & 0,851 & 0,009 & $-0,070$ & 0,823 & 0,955 & 0,999 & 0,999 & 1,00 & - \\
\hline Фітомаса крони, кг & 0,850 & 0,010 & $-0,061$ & 0,815 & 0,955 & 1,00 & 1,00 & 0,999 & 1,00 \\
\hline
\end{tabular}

Отримана кореляційна матриця вказує на тісний зв'язок $(0,776-0,999)$ між всіма зазначеними в таблиці показниками окрім повноти та бонітету.

Проведений статистичний аналіз вказав на однорідну сукупність за середньою висотою та неоднорідну за іншими показниками. Розподіл дуже асимет- ричний, правосторонній за віком, повнотою, бонітетом, об'ємом стовбура та фрітомасою, розподіл помірний за середнім діаметром і лівосторонній за середньою висотою. Коефіцієнт ексцесу вказав на гостровершинний розподіл за повнотою та плосковершинний за рештою показників (табл. 2).

Таблиця 2 - Основні статистичні характеристики біометричних показників та компонентів надземної фітомаси дерев сосни звичайної в абсолютно сухому стані

\begin{tabular}{|c|c|c|c|c|c|c|c|c|c|}
\hline Показники & $\begin{array}{l}\frac{m}{y} \\
\frac{a}{0} \\
\frac{-y}{0}\end{array}$ & 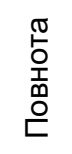 & 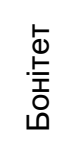 & 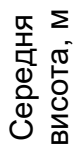 & 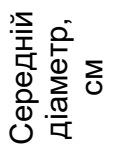 & 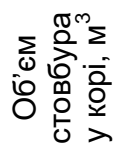 & 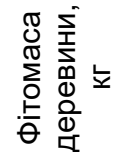 & 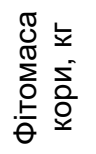 & 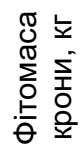 \\
\hline $\begin{array}{c}X_{c p} \text { (середнє арифрметичне } \\
\text { значення) }\end{array}$ & 68,9 & 0,8 & 1,4 & 21,9 & 27,4 & 0,7 & 278,5 & 23,3 & 34,6 \\
\hline$C_{V}$ (стандартна помилка) & 2,9 & 0,1 & 0,1 & 0,5 & 0,9 & 0,1 & 22,3 & 1,8 & 2,1 \\
\hline$\sigma$ (стандартне відхилення) & 29,4 & 0,5 & 0,7 & 5,4 & 9,5 & 0,6 & 227,2 & 18,0 & 21,3 \\
\hline$D$ (дисперсія вибірки) & 862,4 & 0,3 & 0,4 & 28,9 & 90,0 & 0,4 & 51603,1 & 325,7 & 455,0 \\
\hline$E$ (ексцес) & 0,2 & 94,8 & 1,9 & 0,4 & 0,04 & 1,9 & 1,9 & 1,9 & 1,9 \\
\hline$A$ (коефріцієнт асиметрії) & 0,7 & 9,5 & 1,6 & $-0,5$ & 0,4 & 1,4 & 1,4 & 1,4 & 1,4 \\
\hline V (коефріцієнт варіації), \% & 42,6 & 69,1 & 46,9 & 24,5 & 34,6 & 81,1 & 81,6 & 77,3 & 61,6 \\
\hline $\min$ (мінімум) & 8,0 & 0,4 & 1,0 & 3,0 & 2,0 & 0,01 & 4,9 & 0,4 & 8,9 \\
\hline $\max$ (максимум) & 150,0 & 6,0 & 4,0 & 32,0 & 52,0 & 2,9 & 1095,1 & 88,6 & 111,4 \\
\hline
\end{tabular}

Для пошуку математичних моделей взаємозв'язку конверсійних коефіцієнтів соснових насаджень застосовувалась функція:

$$
R_{v}=f(\mathrm{~A}, \mathrm{Б}, \Pi, \mathrm{M}) \text {, }
$$

де $R_{v}$ - відповідні конверсійні коефріцієнти для кожної фрітофрракції дерева; А, Б, П, М - вік, бонітет, повнота, запас насадження у корі $[10 ; 20]$.

Як залежна змінна нами використовувалось відношення маси фракції фітомаси до стовбурового запасу деревостану в корі:

$$
R_{v}=\frac{M_{f r}}{M} .
$$

де $R_{v}$ - конверсійний коефріцієнт, $M_{f r}$ - маса фракції фрітомаси в абсолютно сухому стані, т/га, $M-$ запас деревостану у корі, м³/га [10; 18; 20].

3 метою отримання емпіричних рівнянь $R_{v}$ були використані показники тимчасових пробних площ, на яких встановлювалась фітомаса за рівняннями 1, 2.

У ході математичного моделювання отримані наступні рівняння:

$$
\begin{array}{cc}
\text { для деревини } & \\
R_{v(\text { дер })}=0,346 \times A^{0,021} & R^{2}=0,70 ; \\
\text { для кори } & \\
R_{v(\text { кори })}=0,060 \times A^{-0,143} & R^{2}=0,72 ;
\end{array}
$$

для крони 


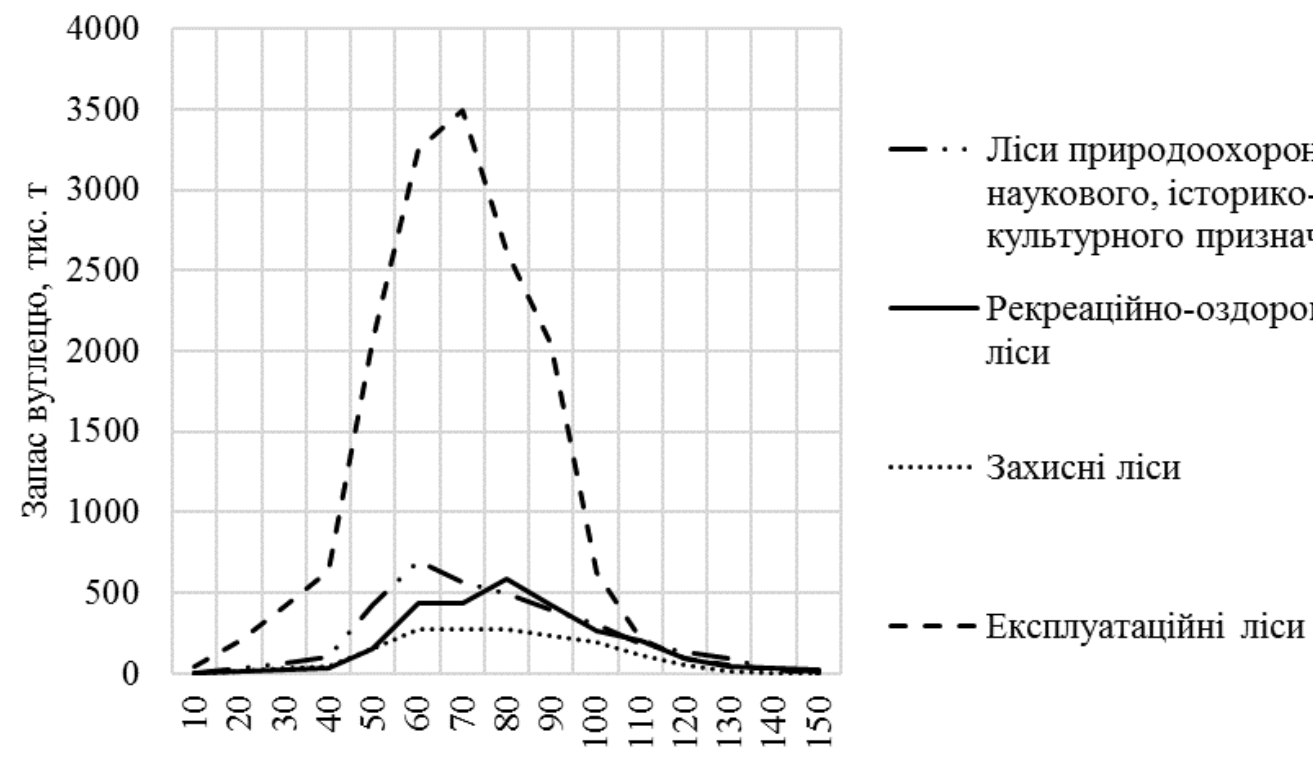

Роки

Рис. 5. Запас вуглецю у соснових насадженнях Житомирського Полісся за категорією лісів

Таблиця 3 - Порівняльні дані антропогенних викидів вуглецю та його депонування сосновими лісами Житомирського Полісся

\begin{tabular}{|c|c|c|c|c|}
\hline Роки & $\begin{array}{c}\text { Кількість депоно- } \\
\text { ваного вуглецю } \\
\text { за роками, млн т }\end{array}$ & $\begin{array}{c}\text { Загальний обсяг } \\
\text { щорічного поглинан- } \\
\text { ня вуглецю, млн т }\end{array}$ & $\begin{array}{c}\text { Щорічні викиди вуг- } \\
\text { лецю в атмоссрерне } \\
\text { повітря, млн т }\end{array}$ & $\begin{array}{c}\text { Різниця між викидами та } \\
\text { депонуванням вуглецю } \\
\text { за рік, млн т }\end{array}$ \\
\hline 2004 & 24,0 & - & - & - \\
\hline 2005 & 24,0 & 0,005 & 0,20 & 0,20 \\
\hline 2006 & 24,0 & 0,006 & 0,60 & 0,59 \\
\hline 2007 & 24,0 & 0,006 & 1,40 & 1,39 \\
\hline 2008 & 24,0 & 0,007 & 1,50 & 1,69 \\
\hline 2009 & 24,0 & 0,008 & 1,70 & 1,59 \\
\hline 2010 & 24,0 & 0,009 & 1,60 & 1,49 \\
\hline 2011 & 24,0 & 0,009 & 1,50 & 1,59 \\
\hline 2012 & 24,0 & 0,010 & 1,60 & 1,69 \\
\hline 2013 & 24,1 & 0,010 & 1,70 & 1,49 \\
\hline 2014 & 24,1 & 0,011 & 1,50 & 1,39 \\
\hline 2015 & 24,1 & 0,012 & 1,40 & 0,69 \\
\hline 2016 & 24,1 & 0,012 & 0,70 & 0,69 \\
\hline 2017 & 24,1 & 0,013 & 0,70 & 0,79 \\
\hline 2018 & 24,1 & 0,013 & 0,80 & \\
\hline
\end{tabular}

З 2004 р. - по автомобільному, залізничному транспорту; з 2007 р. - по автомобільному, залізничному транспорту та виробничій техніці

Щорічно соснові ліси Житомирського Полісся поглинають від 5,0-13,0 тис. т вуглецю з повітря, знижуючи щорічні викиди діоксиду вуглецю на $0,5-2,3 \%$.

Втрата 243 тис. га соснових насаджень через всихання спричиняє не тільки екологічні проблеми але й економічні, адже Україна мала би значні прибутки від продажу квот на світовому ринку, беручи активну участь у Паризькій угоді.

Висновки. Проаналізовано кліматичні зміни в регіоні дослідження, встановлено зростання середньорічної температури повітря на $2,5^{\circ} \mathrm{C}$ за період 1968-2018 рр., такі зміни спричиняють втрату соснових насаджень.

За допомогою отриманих емпіричних рівнянь встановлено, що експлуатаційні соснові ліси, які переважають у Житомирському Поліссі, у віці 70 років у своїй фітомасі накопичують 3,5 млн т вуглецю.

3'ясовано, що соснові насадження Житомирського Полісся щорічно поглинають від 5,013,0 тис. т, знижуючи викиди парникових газів від стаціонарних та пересувних джерел забруднення від 0,5 до 2,3\%.

\section{СПИСОК ВИКОРИСТАНОÏ ЛІТЕРАТУРИ:}

1. Аналітичний документ. Європейська система торгівлі викидами та перспективи впровадження системи торгівлі викидами в Україні. Експертно-дорадчий центр «Правова аналітика». 2018. вересень. 26 с. 
2. Аткин А.С., Аткина Л.И. Способ и динамика органической массы в лесных сообществах. Екатеринбург : Изд. УГЛТА, 1999. 108 с.

3. Боровиков А.М., Уголев Б.Н. Справочник по древесине : справочник. Москва : Лесн. пром-сть, 1989. 296 c.

4. Букша І.Ф., Бутрим О.В., Пастернак В.П. Інвентаризація парникових газів у секторі землекористування та лісового господарства : монографрія. Харків : ХНАУ, 2008. 232 с.

5. Герасимович А.И., Матвеева Я.И. Математическая статистика. Минск : «Вышэйшая школа», 1978. $200 \mathrm{c}$.

6. Демаков Ю.П., Пуряев А.С., Черных В.Л., Черных Л.В. Использование аллометрических зависимостей для оценки фитомассы различных фракций деревьев и моделирования их динамики. Вестник Поволжского государственного технологического университета. Сер.: Лес. Экология. Природопользование. 2015. № 2 (26). С. 19-36.

7. Кашпор С.М., Строчинський А.А. Лісотаксаційний довідник. Київ : Вид. дім «Вінніченко», 2013. 496 c.

8. Киотский протокол. История развития, цели и принципы. Проекты совмесного осуществления в Украине: сборник информационно-методических материалов / под. ред. С.В. Третьякова. Донецк : ООО «УКРДРУК», 2006. 184 с.

9. Кобзарь А.И. Прикладная математическая статистика. Для инженеров и научных работников. Москва : ФИЗМАТЛИТ, 2006. 816 с.

10. Лакида П.І. Фітомаса лісів України : монографія. Тернопіль : Збруч, 2002. 256 с.

11. Паризька угода ООН. Угода. Міжнародний документ від 12.12.2015 р. Київ. 2014. URL: http://zakon2.rada.gov.ua/laws/show/995_161.

12. Партнерство заради ринкової готовності в Україні (PMR). Пропозиції щодо розвитку інструментів вуглецевого ціноутворення в Україні: звіт 3 моделювання. Partnership for market readiness. Серпень 2019. 69 с.

13. Полубояринов О.И. Плотность древесины. Москва : Лесн. пром-сть, 1976.160 с.

14. Почтовюк А.Б., Пряхина Е.А. Торговля квотами как один из механизмов Киотского протокола. Проблемы современной экономики. СанктПетербург. 2012. № 3 (43). С. 300-304.

15. Публічний звіт т.в.о. Голови Державного агентства лісових ресурсів України за 2018 рік. Київ, 2018.

16. Соловій І. Оцінка міжнародного досвіду та процедур/регулювань щодо концепції плати за послуги екосистем в лісовому секторі. ENPI EAST FLEG II. September. European Union. 2016. 64 c.

17. Способ определения надземной фитомассы лесных насаждений : пат. Российской федерации на способ изобретения. № 2272402 C2 / Алексеев И.А., Курненкова И.П., Чешуин А.Н., Бердинских С.Ю., Степанова Т.В., Вахрушев К.В., Коток О.Н.; патентообладатель Марийский государстванный технический университет; заявл. 25.03.2004; опубл. 27.03.2006. № 9. 6 с.

18. Чуроков Б.П., Манякина Е.В. Депонирование углерода разновозрастными культурами сосны. Ульяновский медико-биологический журнал. 2012. № 1. C 125-129.
19. Швиденко А.3., $\quad$ Строчинский А.А., вич Ю.Н., Кашпор С.Н. Нормативно-справочные материалы для таксации лесов Украины и Молдавии. Киев : Урожай, 1987. 560 с.

20. Щепащенко Д.Г., Швиденко А.3., Шалаев В.С. Биологическая продуктивность и бюджет углерода лиственничных лесов Северо-Востока России : монография. Москва : ГОУ ВПО МГУЛ, 2008. 296 c.

\section{REFERENCES:}

1. Analitichniy dokument. (2018). Evropeyska sistema torgivli vikidami ta perspektivi vprovadzhennya sistemi torgivli vikidami v Ukrayini. Ekspertno-doradchiy tsentr "Pravova analitika» [The analytical document. European Emissions Trading Scheme and Prospects for Emissions Trading in Ukraine. Legal Analytics Expert Advisory Center]. Berezen. [in Ukrainian]

2. Atkin A.S., Atkina L.I. (1999). Sposob $i$ dinamika organicheskoy massyi $v$ lesnyih soobschestvah [The method and dynamics of organic matter in forest communities]. Ekaterinburg : izd. Uralskaya gosudarstvennaya lesotehnicheskaya akademiya. [in Russian]

3. Borovikov A.M., Ugolev B.N. (1989). Spravochnik po drevesine: spravochnik [Wood Handbook]. Moskva : Lesnaya promyishlennost. [in Russian]

4. Buksha I.F., Butrim O.V., Pasternak V.P. (2008). Inventarizatsiya parnikovih gaziv u sektori zemlekoristuvannya ta lisovogo gospodarstva: monograflya [Taking of inventory of greenhouse gases is in the sector of land-tenure and forestry]. Harkiv : HNAU. [in Ukrainian]

5. Gerasimovich A.I., Matveeva Ya.I. (1978). Matematicheskaya statistika [Math statistics]. Minsk : «Vyisheyshaya shkola». [in Belorussia]

6. Demakov Yu.P., Puryaev A.S., Chernyih V.L., Chernyih L.V. (2015). Ispolzovanie allometricheskih zavisimostey dlya otsenki fitomassyi razlichnyih fraktsiy derevev i modelirovaniya in dinamiki [The use of allometric dependencies for assessing the phytomass of various fractions of trees and modeling their dynamics]. Vestnik Povolzhskogo gosudarstvennogo tehnologicheskogo universiteta Ser.: Les. Ekologiya. Prirodopolzovanie - Bulletin of the Volga State Technological University. Series: Forest. Ecology. Nature management, 2(26), 19-36. [in Russian]

7. Kashpor, S.M., Strochinskiy, A.A. (2013). Lisotaksatslyniy dovidnik [Forestry Directory]. Kyiv : «Vinnichenko». [in Ukrainian]

8. Tretyakov, S.V. (Ed.). (2006). Kiotskiy protokol. Istoriya razvitiya, tseli i printsipyi. Proektyi sovmestnogo osuschestvleniya $v$ Ukraine [The Kyoto Protocol. History of development, goals and principles. Joint implementation projects in Ukraine]. Sbornik informatsionno-metodicheskih materialov Collection of information and methodological materials. Donetsk. [in Ukrainian]

9. Kobzar, A.I. (2006). Prikladnaya matematicheskaya statistika. Dlya inzhenerov $i$ nauchnyih rabotnikov [Applied Mathematical Statistics. For engineers and scientists]. Moskva : FIZMATLIT. [in Russian]

10. Lakida P.I. (2006). Fitomasa lisiv Ukrayini: monografiya [Phytomass of the forests of Ukraine]. Ternopil : Zbruch. [in Ukrainian] 
11. Parizka ugoda OON. Ugoda. Mizhnarodniy dokument vid 12.12.2015. (2014). [UN Paris Agreement. Agreement. International document dated 12.12.2015]. URL: http://zakon2.rada.gov.ua/laws/ show/995 161.

12. Partnerstvo zaradi rinkovoyi gotovnosti v Ukrayini (PMR). Propozitsiyi schodo rozvitku Instrumentiv vugletsevogo tsinoutvorennya v Ukrayini: zvit z modelyuvannya [Partnership for Market Readiness in Ukraine (PMR). Proposals for developing carbon pricing tools in Ukraine: a simulation report]. (2019). Partnership for market readiness. [in Ukrainian]

13. Poluboyarinov, O.I. (1976). Plotnost drevesinyi [Wood density]. [in Russian]

14. Pochtovyuk, A.B., \& Pryahina, E.A. (2012). Torgovlya kvotami kak odin iz mehanizmov Kiotskogo protokola [Quota trading as one of the mechanisms of the Kyoto Protocol]. Problemyi sovremennoy ekonomiki - Problems of the modern economy, 3(43), 300-304. [in Russian]

15. Publichniy zvit t.v.o. Golovi Derzhavnogo agentstva Ilsovih resurslv Ukrayini za 2018 rik [Public Report of the Head of the State Forest Resources Agency of Ukraine for 2018]. (2018). Kyiv. [in Ukrainian]

16. Soloviy Ihor. (2016). Interim Report on the international experience and procedure/regulations of payments for ecosystem services (PES) concept in forest sector. ENPI EAST FLEG II. September. European Union. [in English]

17. Alekseev, I.A., Kurnenkova, I.P., Cheshuin, A.N., Berdinskih, S.Yu., Stepanova, T.V., Vahrushev, K.V., \& Kotok, O.N. (2006). Sposob opredeleniya nadzemnoy fitomassyi lesnyih nasazhdeniy: pat. Rossiyskoy federatsii na sposob izobreteniya [A method for determining the aboveground phytomass of forest stands: US Pat. Russian Federation on the method of invention]. Patent of Russia. № 2272402 C2. [in Russian]

18. Churokov, B.P., \& Manyakina, E.V. (2012). Deponirovanie ugleroda raznovozrastnyimi kulturami sosnyi [Carbon deposition by pine crops of different ages]. Ulyanovskiy mediko-biologicheskiy zhurnal Ulyanovsk Medical and Biological Journal, 11, 125-129. [in Russian]

19. Shvidenko, A.Z.

Strochinskiy, A.A., Savich, Yu.N., \& Kashpor, S.N. (1987). Normativnospravochnyie materialyi dlya taksatsii lesov Ukrainyi i Moldavii [Normative and reference materials for taxation of forests of Ukraine and Moldova]. Kyiv : Urozhay. [in Ukrainian]

20. Schepaschenko, D.G., Shvidenko, A.Z., \& Shalaev, V.S. (2008). Biologicheskaya produktivnost $i$ byudzhet ugleroda listvennichnyih lesov SeveroVostoka Rossii: monografiya [Biological productivity and carbon budget of larch forests of the North-East of Russia]. Moskva : GOU VPO MGUL. [in Russian]

\title{
ВМІСТ БІЛКА В ЗЕРНІ ПШЕНИЦІ ОЗИМОЇ ЗАЛЕЖНО ВІД ПОГОДНИХ УМОВ У РАННЬОВЕСНЯНИЙ ПЕРІОД
}

\author{
МОСТІПАН М.І. - кандидат біологічних наук, профессор \\ https://orcid.org/0000-0001-5317-6315 \\ КОВАЛЬОВ М.М. - кандидат сільськогосподарських наук \\ https://orcid.org/0000-0003-4421-8960 \\ Центральноукраїнський національний технічний університет \\ УМРИХІН Н.Л. - кандидат сільськогосподарських наук \\ https://orsid.org/0000-0002-4220-8606 \\ Інститут сільського господарства Степу \\ Національної академії аграрних наук України
}

Постановка проблеми. Пшеничне зерно, завдячуючи своєму хімічному складу, є найбільш придатним для виготовлення хлібобулочних виробів. Їх якість визначається, насамперед, вмістом білка та клейковини в зерні пшениці.

Вміст білка в зерні пшениці озимої - це результат численних фрізіолого-біохімічних процесів у рослинах, які тісно взаємопов'язані між собою та умовами оточуючого середовища. Головною умовою синтезу білків у зерні пшениці $є$ поглинання рослинами азоту 3 ґрунту та накопичення його в надземних вегетативних органах $[1 ; 2]$. Тому розміщення пшениці озимої після кращих попередників та забезпечення її достатнім азотним живленням $€$ найбільш ефективними та керованими агротехнічними прийомами підвищення білковості зерна. У Північному Степу України доведена незаперечна роль азотних добрив як основного агротехнічного прийому щодо забезпечення високого вмісту білка в зерні пшениці озимої [3]. Зокрема, в дослідженнях автора встановлено, що внесення азотних добрив підвищувало вміст білка в зерні пшениці озимої по чорному пару з 12,62 до 13,70\% [4]. Серед інших агротехнічних прийомів великий вплив на білковість зерна пшениці озимої справляють строки сівби [5]. За даними А.І. Кривенко [6], вміст білка в досліджуваних сортів пшениці озимої в умовах Південного Степу України на $61,3 \%$ залежав від строків сівби і навіть перевищував вплив генетичних факторів.

Водночас багато авторів звертають увагу на величезну роль умов оточуючого середовища у формуванні якісних показників зерна пшениці озимої. О.О. Созінов, В.Г. Козлов переконані, що білковість зерна пшениці озимої на $70 \%$ залежить від умов оточуючого середовища та на $30 \%$ - від генетичних особливостей сортів [7]. Більш пізнішими дослідженнями І.В. Правдзіва та ін. [8] доведено, що вплив 